\title{
Pengembangan Output Sistem Perhitungan Angka Kredit Petugas Rekam Medis di RSUD Kabupaten Karanganyar
}

\author{
Ade Irma Rahmawati ${ }^{1}$, Nur Rokhman ${ }^{2}$ \\ Diploma III Rekam Medis Sekolah Vokasi Universitas Gadjah Mada ${ }^{1,2}$ \\ ade.irma.r@mail.ugm.ac.id ${ }^{1}$, nurrokhman@mail.ugm.ac.id ${ }^{2}$
}

\begin{abstract}
Abstrak
Latar Belakang: Perekam medis memiliki wewenang dan tanggung jawab untuk melakukan kegiatan pelayanan rekam medis yang diduduki oleh PNS. Pengangkatan pegawai disesuaikan dengan jenjang jabatan dalam jabatan fungsional perekam medis dan ditetapkan berdasarkan jumlah angka kredit yang dimiliki oleh petugas. Perekam medis yang tidak dapat mengumpulkan angka kredit dalam sesuai dengan ketetapan yang berlaku dapat dibebaskan sementara dari jabatannya atau diberhentikan jabatan fungsional sebagai perekam medis. Proses perhitungan angka kredit masih terkendala beban kerja petugas yang tinggi dan perhitungan angka kredit yang masih manual dengan perhitungan berdasarkan satuan angka kredit yang berbentuk angka desimal, sehingga membuat petugas mengalami kesulitan dalam proses penghitungan serta terkadang petugas mengalami kesulitan saat melakukan rekap setiap bulannya.

Tujuan: Merancang output sistem perhitungan angka kredit petugas rekam medis di RSUD Kabupaten Karanganyar yang disesuaikan dengan kebutuhan petugas untuk mempermudah petugas rekam medis dalam perhitungan angka kredit.

Metode: Identifikasi kebutuhan pengguna pada perancangan ini dilakukan dengan metode pengumpulan data yaitu studi pendahuluan dan wawancara. Alat pengumpulan data dengan instrumen wawancara dan perekam suara. Perancangan dilakukan dengan aplikasi Sublime Text 3 dengan bantuan Codeigniter untuk pengkodean dan bootstrap untuk desain antarmuka.

Hasil: Berdasarkan hasil analisis dan wawancara kebutuhan pengguna kepada petugas rekam medis yang telah menjabat sebagai Pegawai Negeri Sipil (PNS), maka dihasilkan output sistem perhitungan rekam medis berupa database sistem, antarmuka output sistem dan laporan perhitungan angka kredit.

Kesimpulan: Perancang telah melakukan perancangan output sistem perhitungan angka kredit meliputi database sistem, antarmuka output sistem dan laporan perhitungan angka kredit.

Kata Kunci: sistem, output, angka kredit, rekam medis.
\end{abstract}

\begin{abstract}
Background: Medical recoder have the authority and the responsibility to do for services medical record occupied by civil servants. Removal of employees adapted to the level of office in position functional medical recorder and determined based on the number of the credit owned by officers. Medical recorder not to be able to get that the credit in accordance command prevailing can be set free while from his position or discharged office functional as medical recorder. The process calculation the credit still obstacle in workload officer who high and calculation the credit still manual by calculation based on a unit of the credit shaped figure decimal, so as to make officers experienced difficulty in the process of calculation and sometimes officers to have difficulties while do companies every month.

Objective: To develop output the calcultion of the credit officers medical record at RSUD Karanganyar District which adjusted with needs officers to ease officers medical record in the calculation of the credit.

Methods: The needs of users on designing this was done in data collection method which is study of introduction and the interview. Instrument data collection with an instrument interview and voice recorder. Design done by any application sublime text 3 with the help of codeigniter to encoding and bootstrap to design interface.
\end{abstract}

Result: based on the result of the analysis and interview needs of users to officers medical record has served as civil servants., so produced output the calculation of medical record of a database system, interface output system and reports calculation the credit.

Conclusion: Designer have done design output the calculation of the credit covering a database system, interface output system and reports calculation the credit.

Keywords: system, output, the credit, medical record. 


\section{PENDAHULUAN}

Menurut Undang-Undang Republik Indonesia Nomor 44 Tahun 2009 tentang Rumah Sakit, rumah sakit sebagai institusi pelayanan kesehatan harus memiliki tenaga tetap yang meliputi tenaga medis dan penunjang medis, tenaga keperawatan, tenaga kefarmasian, tenaga manajemen rumah sakit, dan tenaga non kesehatan. Sebagai tenaga kesehatan yang akan memberikan pelayanan kepada pasien, tenaga kesehatan harus memiliki ijin praktik sesuai dengan peraturan perundangundangan yang berlaku.

Tenaga kesehatan yang dimaksud Undang-Undang Republik Indonesia Nomor 36 Tahun 2014 tentang Tenaga Kesehatan dikelompokkan sebagai tenaga medis, tenaga psikologi klinis, tenaga keperawatan, tenaga kebidanan, tenaga kefarmasian, tenaga kesehatan masyarakat, tenaga kesehatan lingkungan, tenaga gizi, tenaga keterapian fisik, tenaga keteknisian medis, tenaga teknik biomedika, tenaga kesehatan tradisional dan tenaga kesehatan lainnya. Perekam medis merupakan salah satu bagian dari tenaga keteknisian medis.

Berdasarkan Peraturan Menteri Kesehatan Republik Indonesia Nomor 46 Tahun 2013 tentang Registrasi Tenaga Kesehatan, setiap tenaga kesehatan yang akan menjalankan profesinya wajib memiliki Surat Tanda Registrasi atau disingkat STR. STR dapat diperoleh setelah perekam medis mengikuti uji kompetensi dan dinyatakan lulus. Perekam medis yang lulus akan mendapatkan sertifikat kompetensi yang berlaku selama lima tahun terhitung sejak tanggal penerbitan sertifikat kompetensi. Sertifikat kompetensi yang telah habis masa berlakunya dapat diperpanjang setiap lima tahun sekali dengan partisipasi perekam medis dalam pendidikan atau pelatihan serta kegiatan ilmiah lainnya. Kegiatan tersebut dapat dipergunakan apabila memenuhi persyaratan perolehan Satuan Kredit Profesi minimal 25 Satuan Kredit Profesi selama lima tahun. Jumlah satuan kredit dari setiap kegiatan pendidikan atau pelatihan serta kegiatan ilmiah lainnya ditentukan oleh organisasi profesi.

STR yang telah dimiliki oleh perekam medis nantinya akan dipergunakan untuk mendapatkan Surat Ijin Praktik atau disingkat SIP. Selain itu, menurut Peraturan Menteri Pendayagunaan Aparatur Negara dan Reformasi Birokrasi Republik Indonesia Nomor 30 Tahun 2013 tentang Jabatan Fungsional Perekam Medis dan Angka Kreditnya, STR merupakan salah satu syarat bagi perekam medis yang telah menjadi Pegawai Negeri Sipil untuk memiliki jabatan fungsional.

Berdasarkan Peraturan Menteri Pendayagunaan Aparatur Negara dan Reformasi Birokrasi Republik Indonesia Nomor 30 Tahun 2013 Tentang Jabatan Fungsional Perekam Medis dan Angka Kreditnya, perekam medis memiliki jabatan fungsional yang berarti perekam medis mempunyai wewenang dan tanggung jawab untuk melakukan kegiatan pelayanan rekam medis yang diduduki oleh Pegawai Negeri Sipil (PNS). Pengangkatan pegawai disesuaikan dengan jenjang jabatan dalam jabatan fungsional perekam medis dan ditetapkan berdasarkan jumlah angka kredit yang dimiliki oleh pegawai. Unsur kegiatan perekam medis yang dapat dinilai angka kreditnya terdiri dari, pendidikan, pelayanan rekam medis, pengembangan profesi dan penunjang tugas rekam medis.

Perekam medis yang tidak dapat mengumpulkan angka kredit dalam jangka waktu 5 tahun sejak diangkat dalam jabatan/pangkat terakhirnya dibebaskan sementara dari jabatannya. Perekam medis dapat diangkat kembali dalam jabatan fungsionalnya apabila dapat memenuhi angka kredit yang telah ditentukan. Apabila tidak dapat memenuhi angka kredit yang ditentukan maka perekam medis dapat diberhentikan jabatan fungsional sebagai perekam medis atau dicabut SIP nya. Pegawai yang jabatan fungsionalnya dicabut dapat diturunkan jenjang jabatannya dan tidak dapat menjadi perekam medis kembali.

Berdasarkan studi pendahuluan di RSUD Kabupaten karanganyar, proses perhitungan angka kredit masih terkendala beban kerja pegawai yang tinggi dan perhitungan angka kredit yang masih manual dengan perhitungan berdasarkan satuan angka kredit yang berbentuk angka desimal, sehingga membuat petugas mengalami kesulitan dalam proses penghitungan serta terkadang petugas 
mengalami kelabakan saat melakukan rekap setiap bulannya.

Dengan perkembangan teknologi saat ini, diharapakan dapat memberikan solusi untuk masalah diatas. Salah satu solusinya adalah dengan perancangan Sistem Perhitungan Angka Kredit. Sistem ini diharapkan dapat membantu petugas dalam perhitungan angka kredit.

\section{METODE}

Identifikasi kebutuhan pengguna pada perancangan ini dilakukan dengan metode pengumpulan data yaitu studi pendahuluan dan wawancara. Alat pengumpulan data dengan instrumen wawancara dan perekam suara. Perancangan dilakukan dengan aplikasi Sublime Text 3 dengan bantuan Codeigniter untuk pengkodean dan bootstrap untuk desain antarmuka.

\section{HASIL DAN PEMBAHASAN}

Dari hasil wawancara dan analisis kebutuhan pengguna maka dihasilkan desain database, desain proses, desain antarmuka dan desain laporan. Desain database dalam dirancang dalam bentuk Entity Relational Diagram yang berisi sekumpulan entitas di dalam sistem yang saling berhubungan satu sama lain.

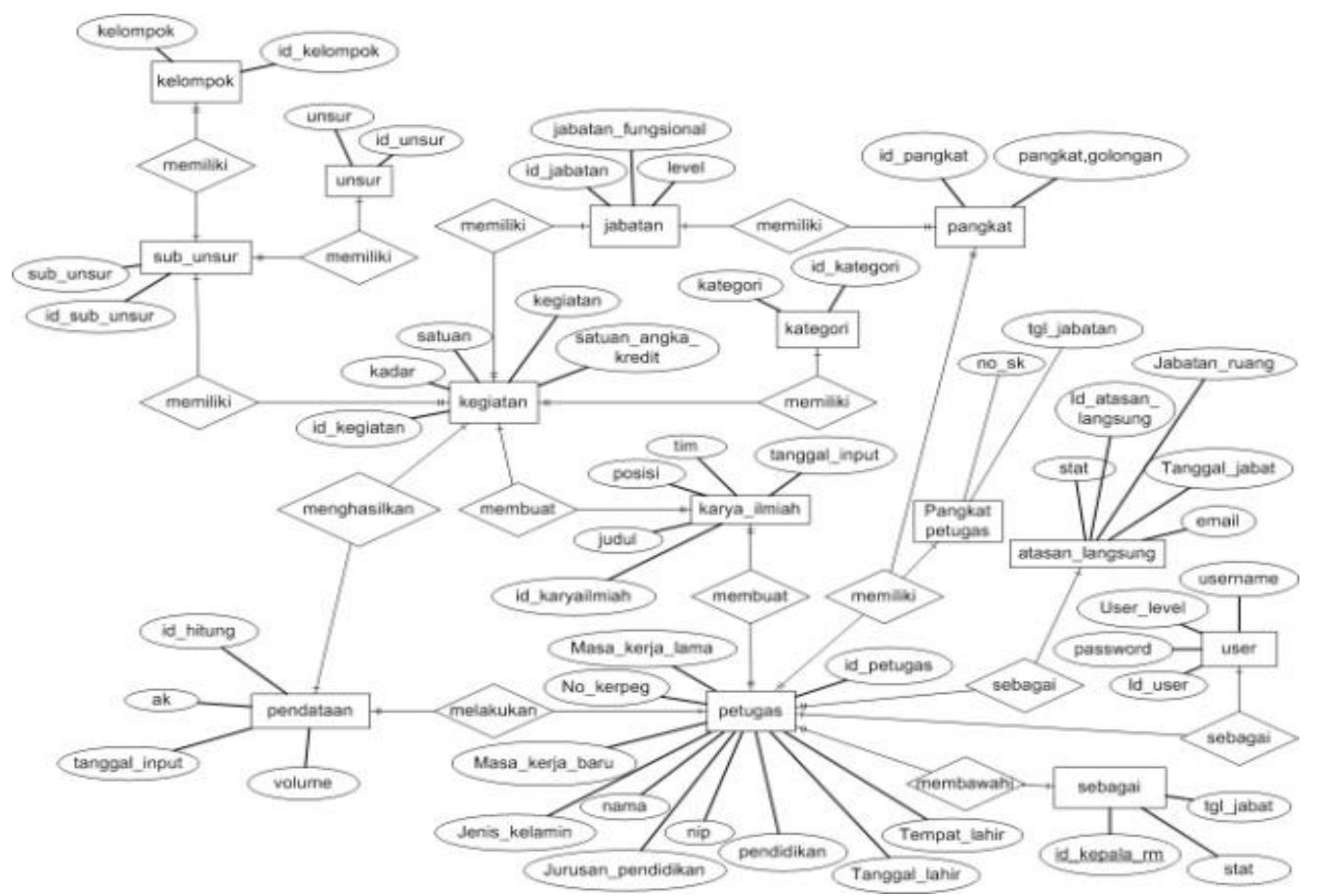

Gambar 1. Entity Relational Diagram

Dari desain database yang telah dibuat akan diwujudkan dalam bentuk tabel relasi.

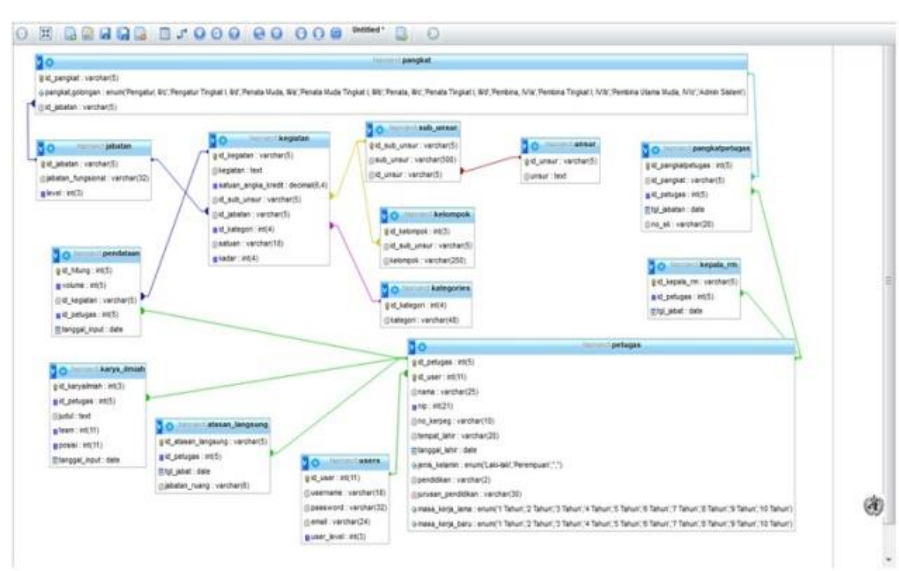

Gambar 2. Tabel Relasi

Desain proses berupa desain diagram alir data yang merupakan gambaran proses dari sebuah sistem. Terdiri dari diagram konteks, DAD level 1 dan DAD level selanjutnya yang memberikan gambaran lebih spesifik. Berikut adalah gambar dari diagram konteks dan DAD level 1 serta DAD level selanjutnya.

Diagram Konteks pada Sistem Informasi Perhitungan Angka Kredit terdiri dari 4 entitas yaitu Admin, Petugas, Kepala RM, dan Atasan Langsung. Entitas admin memberikan masukan ke dalam sistem berupa data user, data pimpinan dan data kegiatan. Admin akan mendapatkan username dan password dari sistem. Entitas petugas, kepala RM dan atasan langsung akan memberikan masukan pada sistem berupa data identitas dan volume kegiatan 
yang telah dilakukan dan mendapatkan output berupa laporan usulan penetapan dan laporan kegiatan.

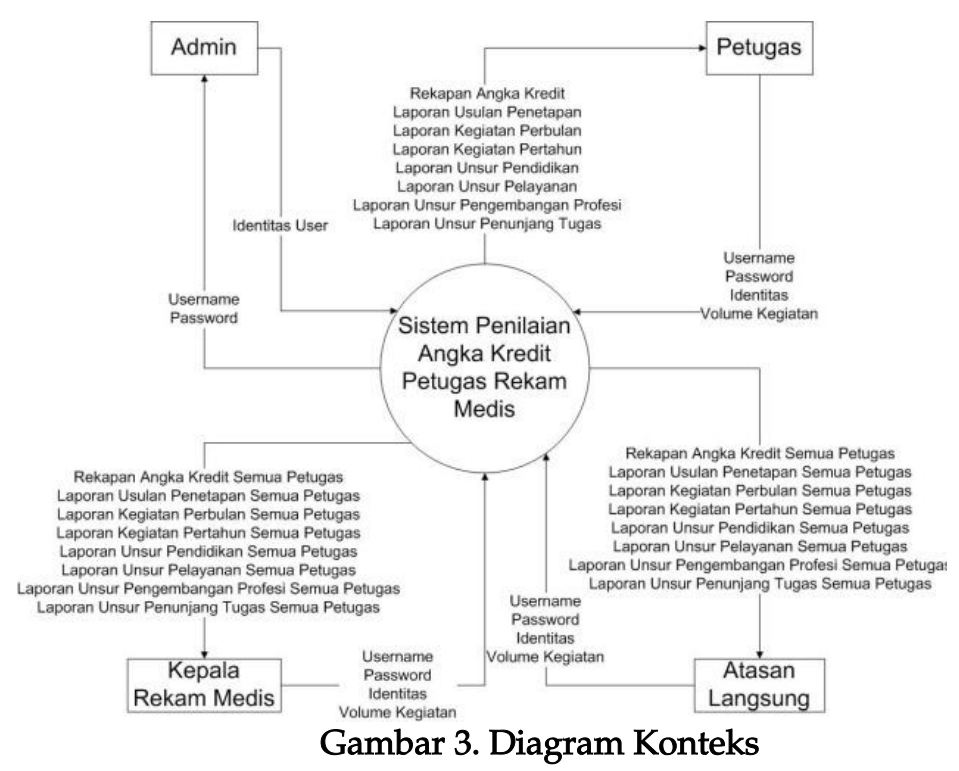

Dari Diagram konteks akan dispesifikan menjadi DAD Level 1 terdiri dari 5 proses yaitu Login, Setting, Entry Volume Kegiatan, Perhitungan Angka Kredit, dan Pelaporan.

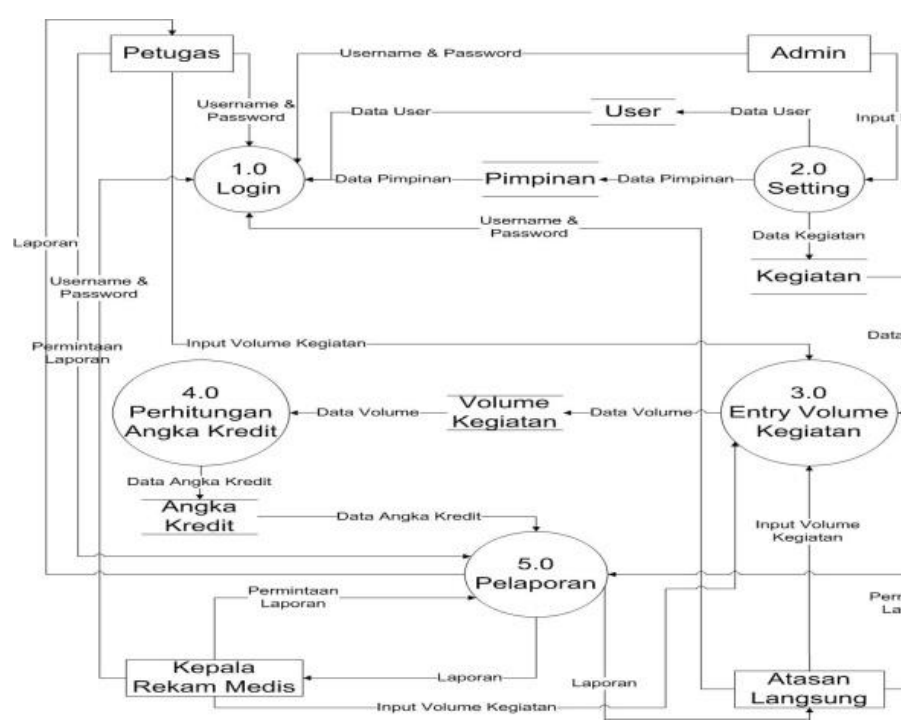

Gambar 4. DAD Level 1

Dari DAD level 1 akan dispesifikan menjadi DAD level 2 yang terdiri dari DAD level 2 setting, DAD level 2 entry volume kegiatan dan DAD level 2 laporan. Penulisan ini ebih berfokus pada output sistem perhitungan angka kredit.

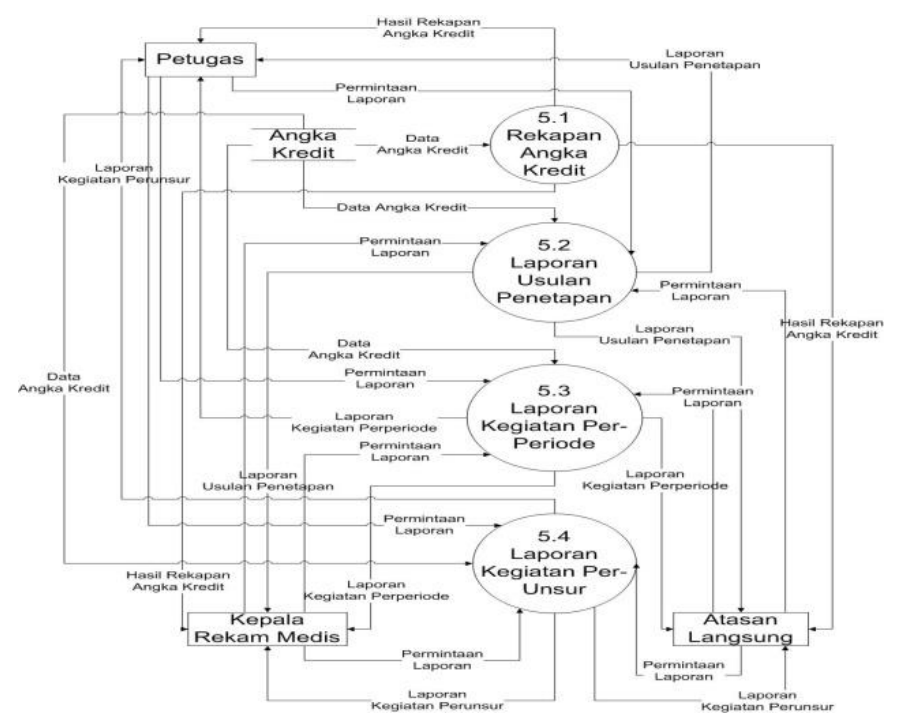

Gambar 5. DAD Level 2 Laporan.

Sedangkan DAD level 3 akan dibuat untuk DAD level 3 laporan per periode dan laporan kegiatan per unsur.

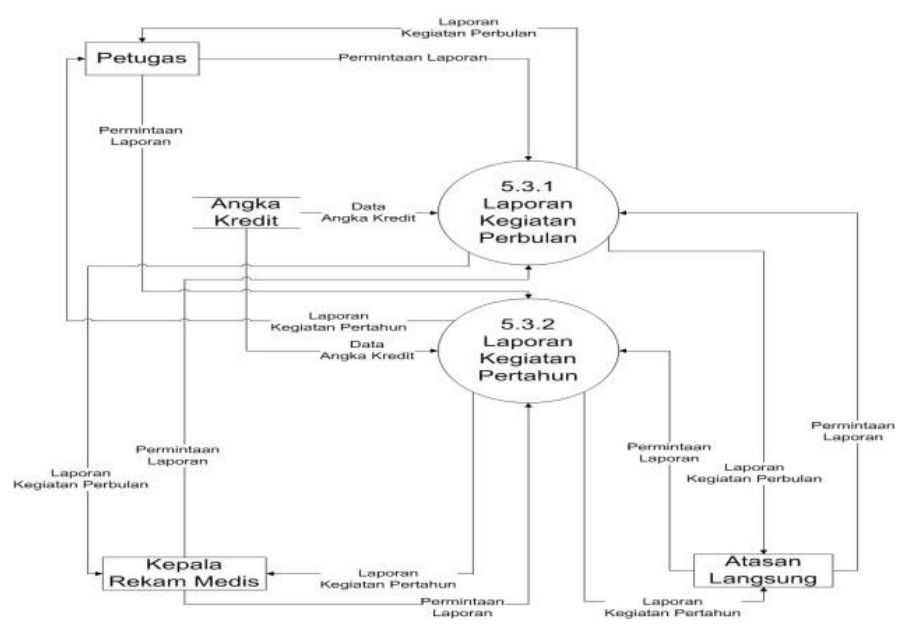

Gambar 6. DAD Level 3 Laporan Kegiatan Per Tahun

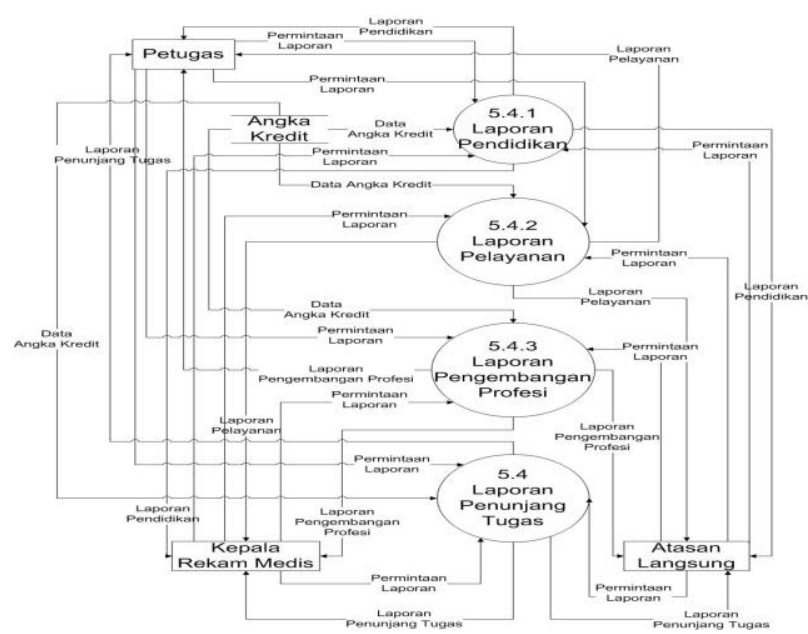

Gambar 7. DAD Level 3 Laporan Kegiatan Per Unsur 
Setelah dilakukan perancangan basis data maka akan dilakukan perancangan desain antarmuka dan desain laporan. Desain antarmuka tersebut akan diwujudkan dalam tampilan antarmuka pada sistem perhitungan angka kredit. Sedangkan desain laporan akan diwujudkan dalam output laporan yang siap cetak.

Tampilan antarmuka output sistem perhitungan angka kredit terdiri dari login, menu kredit, menu rekap dan menu cetak. Pada menu kredit, menu rekap dan menu cetak terdapat perbedaan tampilan untuk petugas dengan admin, kepala RM dan atasan langsung.

Login digunakan untuk masuk ke dalam sistem dengan memasukkan username dan password.

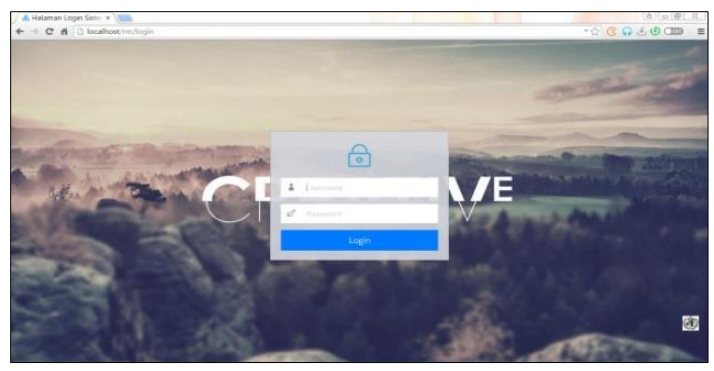

Gambar 8. Login

Menu kredit digunakan untuk melihat riwayat pengisian volume kegiatan.

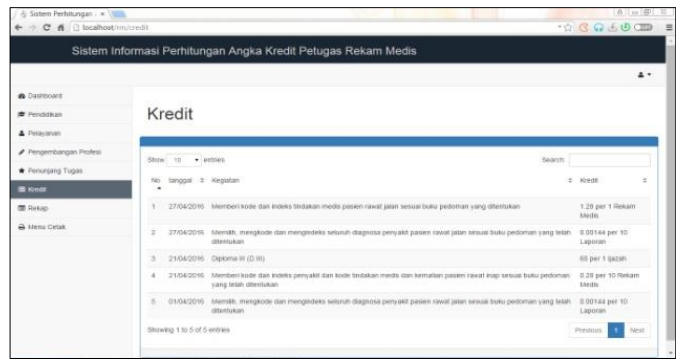

Gambar 9. Menu Kredit Petugas

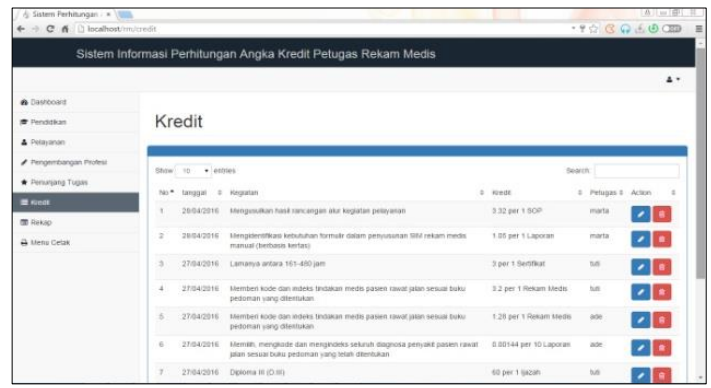

Gambar 10. Menu Kredit Admin, Kepala RM dan Atasan Langsung

Menu rekap digunakan untuk melihat rekapan dari angka kredit yang telah dihasilkan. Menu rekap dikelompokan sesuai dengan unsur kegiatan yaitu, pendidikan, pelayanan, pengembangan profesi dan penunjang tugas

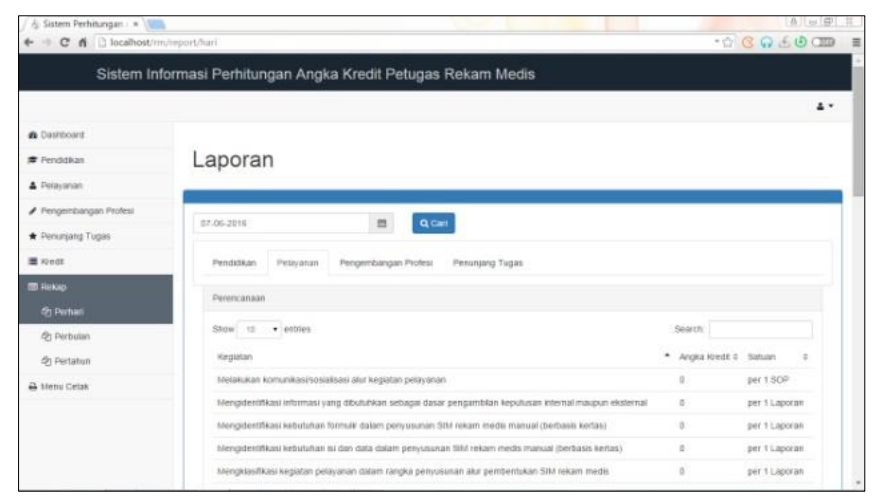

Gambar 11. Menu Rekap Petugas

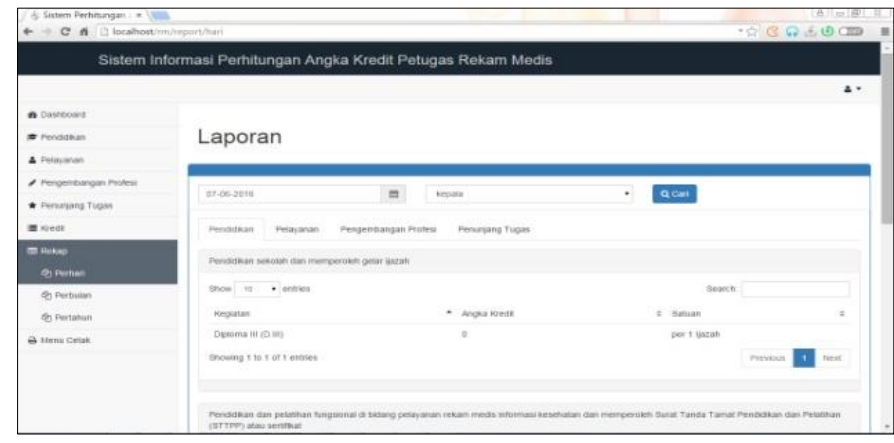

Gambar 12. Menu Rekap Admin, Kepala RM dan Atasan Langsung.

Menu cetak cetak adalah menu yang digunakan untuk mencetak laporan.

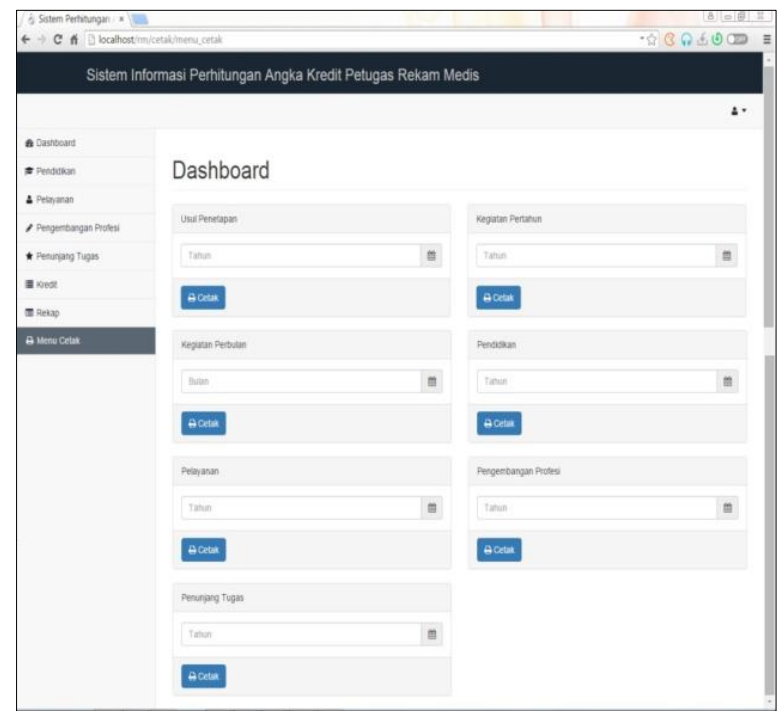

Gambar 13. Menu Cetak Petugas 


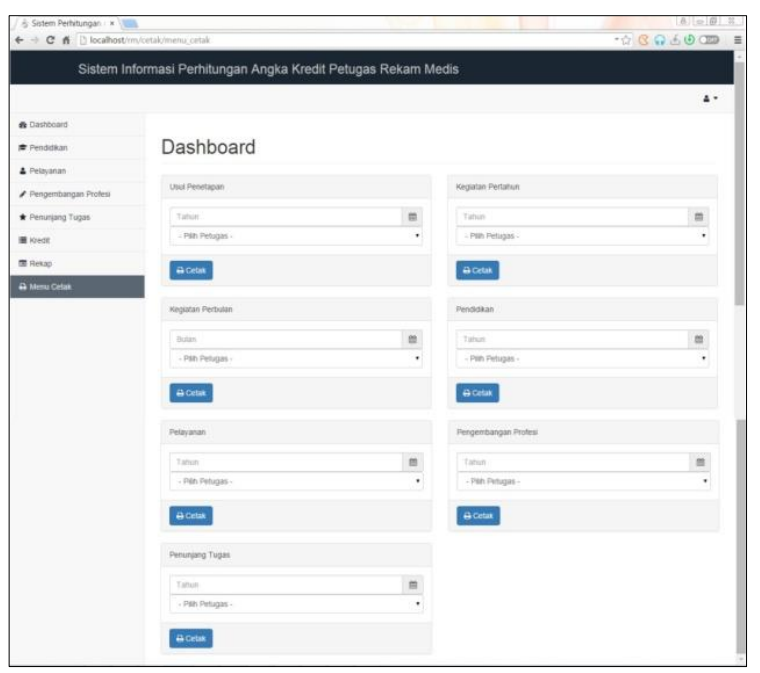

Gambar 14. Menu Cetak Admin, Kepala RM dan Atasan Langsung

Dari menu cetak akan dihasilkan output laporan yang dikelompokkan berdasarkan usulan penetapan, laporan kegiatan per periode dan laporan kegiatan per unsur.

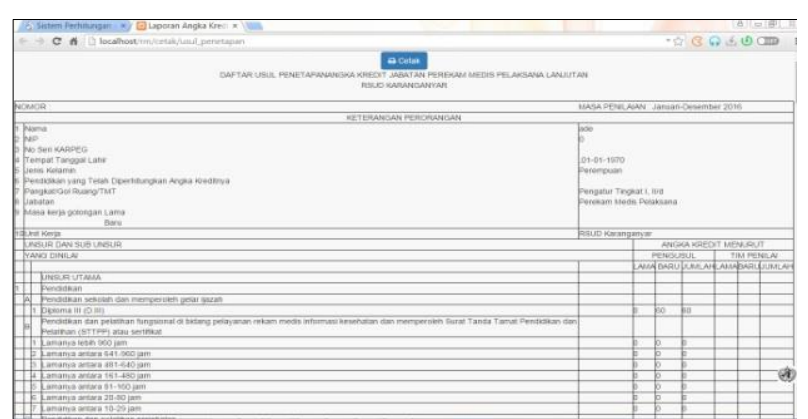

Gambar 15. Laporan Usulan Penetapan

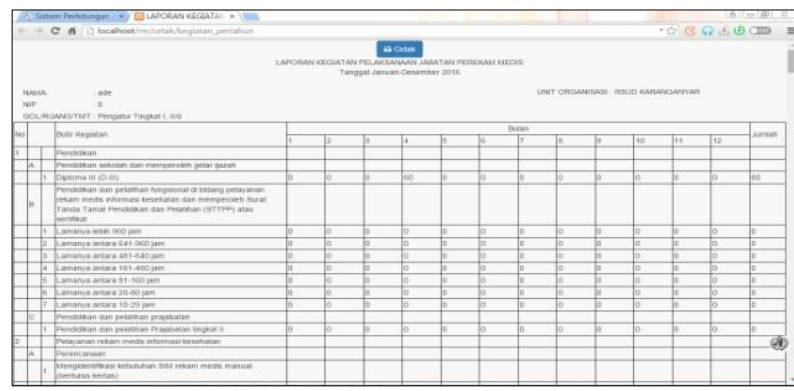

Gambar 16. Laporan Kegiatan Per Tahun

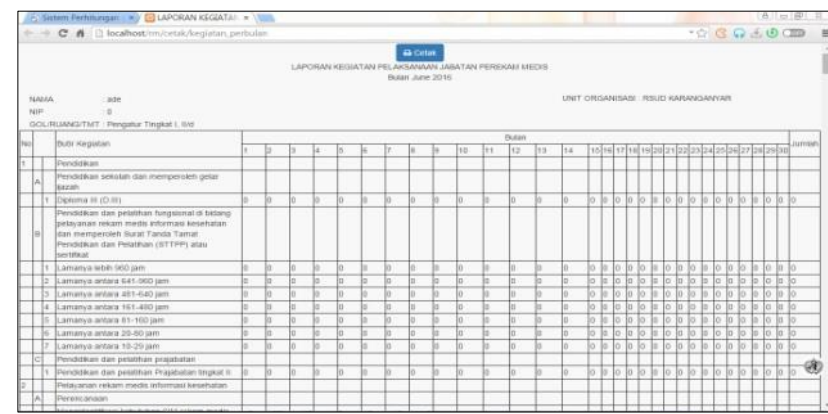

Gambar 17. Laporan Kegiatan Per Bulan

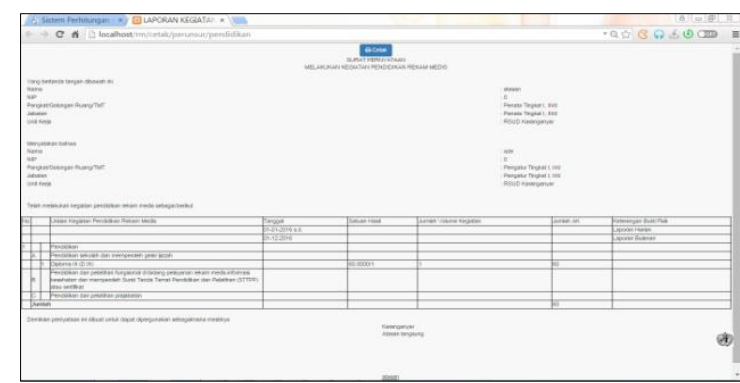

Gambar 18. Laporan Unsur Pendidikan

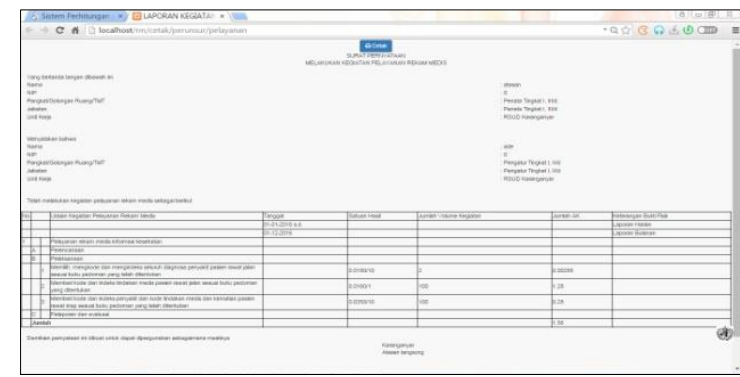

Gambar 19. Laporan Unsur Pelayanan

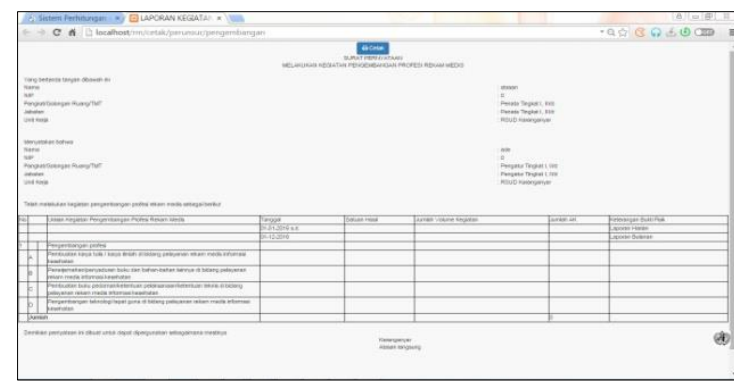

Gambar 20. Laporan Unsur Pengembangan Profesi

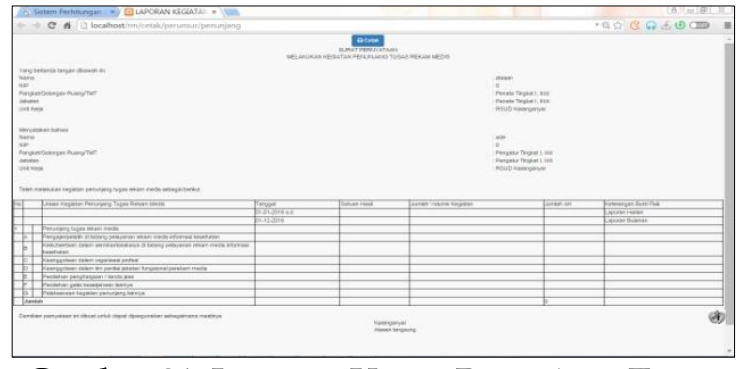

Gambar 21. Laporan Unsur Penunjang Tugas

\section{PENUTUP}

\section{Kesimpulan:}

Proses perhitungan angka kredit di RSUD Kabupaten Karanganyar masih manual dengan perhitungan berdasarkan satuan angka kredit yang berbentuk angka desimal, sehingga membuat petugas mengalami kesulitan dalam proses penghitungan dan saat melakukan rekap setiap bulannya. Pada tugas akhir ini, perancang telah melakukan perancangan pada proses output sistem perhitungan angka kredit dengan menghasilkan keluaran data dari hasil 
pengolahan sistem, mendesain antarmuka tampilan output dan laporan perhitungan angka kredit.

Saran:

1. Sebaiknya perancangan sistem ini dapat dipertimbangkan untuk pengimplementasiaannya agar memudahkan petugas rekam medis dalam proses perhitungan angka kredit.

2. Untuk kedepannya dapat dilakukan pengembangan terhadap sistem perhitungan angka kredit.

\section{DAFTAR PUSTAKA}

Menteri Kesehatan. Peraturan Menteri Kesehatan Republik Indonesia Nomor 46 Tahun 2013 tentang Registrasi Tenaga Kesehatan. bppsdmk.depkes.go.id diakses 11 Januari 2016.

Menpan RI. Peraturan Menteri Pendayagunaan Aparatur Negara dan Reformasi Birokrasi Republik Indonesia Nomor 30 Tahun 2013 tentang Jabatan Fungsional Perekam Medis Dan Angka Kreditnya. WwW.menpan.go.id diakses 15 Desember 2015.

Pemerintah RI. Undang-Undang Republik Indonesia Nomor 36 Tahun 2014 tentang Tenaga Kesehatan. Sinforeg.litbang.depkes.go.id diakses 18 Desember 2015.

Pemerintah RI. Undang-Undang Republik Indonesia Nomor 44 Tahun 2009 tentang Rumah Sakit. www.depkes.go.id diakses 18 Desember 2015. 